Pfizer Inc, Consultant of: AbbVie, Amgen, Eli Lilly, Gema, Genzyme, Novartis and Pfizer Inc, Hendrik Schulze-Koops Grant/research support from: Pfizer Inc DOI: 10.1136/annrheumdis-2020-eular.1432

\begin{tabular}{|l|l}
\hline SAT0140 & SAFETY OF TOFACITINIB THERAPY IN HBSAG \\
& CARRIERS WITH RHEUMATOID ARTHRITIS: A \\
& PROSPECTIVE STUDY
\end{tabular}

L. Fang ${ }^{1}$, Z. Lin' ${ }^{1}$, Z. Liao ${ }^{1}$, O. Jin' ${ }^{1}$, Y. Pan ${ }^{1}$, J. Gu ${ }^{1} .{ }^{1}$ The Third Affiliated Hospital of Sun Yat-sen University, Guangzhou, China

Background: Targeted synthetic DMARDs (ts-DMARDs) are becoming more available and affordable in developing countries, where the prevalence of hepatitis $B$ virus (HBV) infection is still an important public health issue. The safety of ts-DMARDs therapy in terms of the reactivation of hepatitis $B$ virus (HBV) infection need more concern. Rare data from a prospective study focus on the use of ts-DMARDs in patients with concurrent rheumatoid arthritis (RA) and $\mathrm{HBV}$ infection were available by now.

Objectives: To evaluate the influence of tofacitinib on reactivation of $\mathrm{HBV}$ infection in HBsAg carriers with RA.

Methods: In this 52 weeks observation, HBsAg carriers with active RA (DAS28>5.1) despite failed combined treatment with MTX and other non-biological DMARDs were enrolled. Patients must have normal liver function prior to study. All patients received therapy with tofacitinib (5mg twice daily) and concomitant MTX (10-12.5mg/w). Entecavir was prescribed preventively for patients who had a baseline HBV load $>2000 \mathrm{copy} / \mathrm{ml}$ (group 1), and Lamivudin for patients with HBV load $\leq 2000 \mathrm{copy} / \mathrm{ml}$ (group 2). Liver enzymes (AST/ALT) and HBV viral load were monitored every 4 weeks. Increased viral load and abnormal liver function were managed according to expert opinion.

Results: Thirteen patients (10 female) were recruited. Nine patients had a baseline viral load >2000 copy/ml (group 1, with preventive Entecavir), and the other 4 patients had a viral load $\leq 2000 \mathrm{copy} / \mathrm{ml}$ (group 2, with preventive Lamivudin). Two patients from group 1 discontinued tofacitinib at week 12 due to ineffectiveness, and both continued taking Entecavir for another 3 months after the discontinuation of tofacitinib.

No reactivation of hepatitis $B$ was observed in patients from group 1. One patients (female, 54 years old) from group 2 underwent a mild increase of both ALT and AST (67 and $56 \mathrm{IU} / \mathrm{L}$, respectively) at week 16. An elevated viral load (4.9e6 copies/ml, baseline 1.4e3) and a HBV YMDD mutant was also found. The tofacitinib treatment continued. After prescription of Adefovir (combined with the pre-existing Lamivudin), both liver enzyme and viral load decreased to normal range in 8 weeks and remained normal throughout the study.

Conclusion: An aggressive Tofacitinib + MTX therapy may be a safe option for HBsAg carriers with cs-DMARDs refractory RA. More active and effective prophylaxis strategy may be recommended to reduce the risk of HBV reactivation during the treatment.

References:

[1] Chen YM, Huang WN, Wu YD, et al. Reactivation of hepatitis B virus infection in patients with rheumatoid arthritis receiving tofacitinib: a real-world study. Ann Rheum Dis 2018; 77:780-2.

Disclosure of Interests: : None declared

DOI: 10.1136/annrheumdis-2020-eular.6353

\section{SAT0141 LONG-TERM EFFECTIVENESS OF TOFACITINIB IN CONVENTIONAL DMARDS NON-RESPONDERS WITH RHEUMATOID ARTHRITIS: RESULTS OF RUSSIAN NATIONAL REGISTER}

1. Gaydukova ${ }^{1}$, V. Mazurov ${ }^{1}$, A. Lila ${ }^{2}$, A. Baranov ${ }^{3}$, G. Lukina ${ }^{4}$, E. Zhilyaev ${ }^{5}$, E. Koltsova ${ }^{6}$, E. Shmidt ${ }^{7}$, O. Fomina ${ }^{8}$, I. Bondareva ${ }^{9}$, O. Anoshenkova ${ }^{10}$, A. Vasilenko ${ }^{11}$, E. Vasilenko $^{1}$, N. Yudina ${ }^{12}$, L. Knyazeva ${ }^{13}$, V. Poncratov ${ }^{13}$, E. Gaydukova ${ }^{14}$, E. Nasonov ${ }^{2} .{ }^{1}$ North-Western State Medical University named after I. I. Mechnikov, St. Petersburg, Russian Federation; ${ }^{2}$ Nasonova Research Institute of Rheumatology, Moscow, Russian Federation; ${ }^{3}$ Yaroslavl State Medical University, Yaroslavl, Russian Federation; ${ }^{4}$ Moscow Clinical Scientific and Practical Centre named after Loginov AS, Moscow, Russian Federation; ${ }^{5}$ Russian Medical Academy of Post Graduate Education, Moscow, Russian Federation; ${ }^{6}$ Scientific and Research Institute of Health Care Organization, Moscow, Russian Federation; ${ }^{7}$ Municipal Clinical Hospital \# 1 named after NI Pirogov, Moscow, Russian Federation; ${ }^{8}$ Amur Regional Hospital, Blagoveshchens, Russian Federation; ${ }^{9}$ Kemerovo Regional Clinical Hospital, Kemerovo, Russian Federation; ${ }^{10}$ Siberian State Medical University, Tomsk, Russian Federation; ${ }^{11}$ Regional Clinical Hospital, V. Novgorod, Russian Federation; ${ }^{12}$ Republican Hospital No 1 of the Republic of Tuva, Kyzyl, Russian Federation; ${ }^{13}$ Kursk State Medical University, Kursk, Russian Federation; ${ }^{14}$ Clinical Rheumatological Hospital No 25, St. Petersburg, Russian Federation

Background: Tofacitinib is an oral Janus Kinase inhibitor for the treatment of rheumatoid arthritis (RA)
Objectives: To evaluate the three-year effectiveness of tofacitinib in RA conventional synthetic (cs) DMARDs non-responders.

Methods: Data from 374 patients from Russian national register OREL of patients with RA treated with tofacitinib not less than 3 years after failure of conventional DMARDs were included in the statistical analysis. Clinical and laboratory data from 4 consecutive visits with an interval of 12 months between the visits ( \pm 28 days) were analyzed. Treatment with any biologics ever was an exclusion criteria. Demographical (age, sex) and disease-related characteristics of RA (symptoms duration, RFand ACCP positivity, presence of joint erosions, DAS28, CDAI, number of tender and swollen joints (NTJ, NSJ), erythrocytes sedimentation rate (ESR), C-reactive protein (CRP)) collected. Statistical analysis performed with statistical programs SPSS2017 and GraphPadPrizm. p-value $<0.05$ considered as significant.

Results: Baseline characteristics of RA patients, involved in the analysis are presented in table 1.

Table 1. Baseline characteristics of the patients with RA ( $n=374)$.

\begin{tabular}{lc}
\hline Parameter & Characteristics \\
\hline Male, $\mathrm{n}(\%)$ & $92(24.5)$ \\
Age, years (mean \pm SD) & $53.4 \pm 13.38$ \\
Symptoms duration, month (mean \pm SD) & $140 \pm 137$ \\
Positive rheumatoid factor (RF), $\mathrm{n}(\%)$ & $123(32.8)$ \\
Positive antibodies to cyclic citrullinated peptide (ACCP), $\mathrm{n}(\%)$ & $329(87.9)$ \\
Erosions of hand joints (X-rays), $\mathrm{n}(\%)$ & $372(99.4)$ \\
BMl, $\mathrm{kg} / \mathrm{m}^{2}$ (mean \pm SD) & $26.8 \pm 6.14$ \\
Smokers (current and in the past), $\mathrm{n}(\%)$ & $54(14.4)$ \\
\hline
\end{tabular}

Changes in the diseases activity parameters in patients with RA, treated with tofacitinib not less than 3 years after cs DMARD failure are presented in table 2, figure 1, and figure 2.

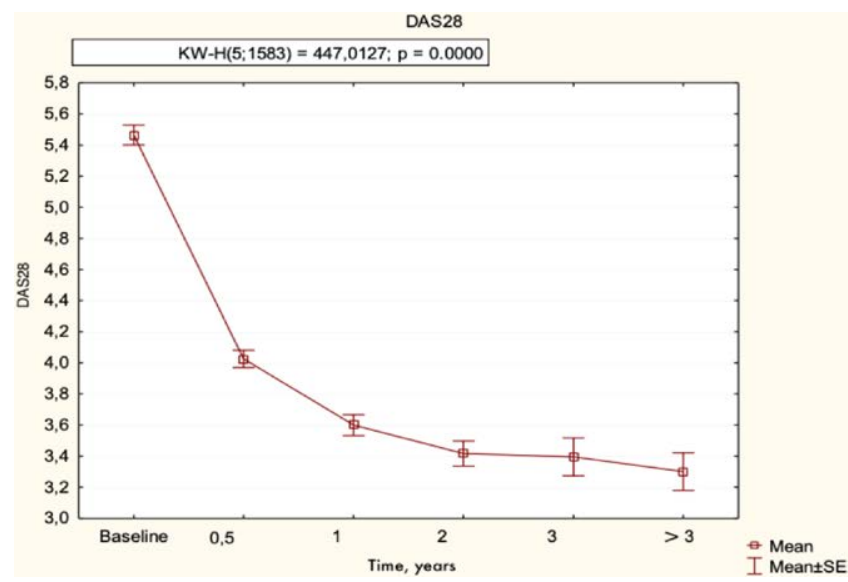

Figure 1. DAS28 of patients with RA, treated with tofacitinib ( $n=374)-3$-years follow-up (timepoints are presented in years \pm 28 days).

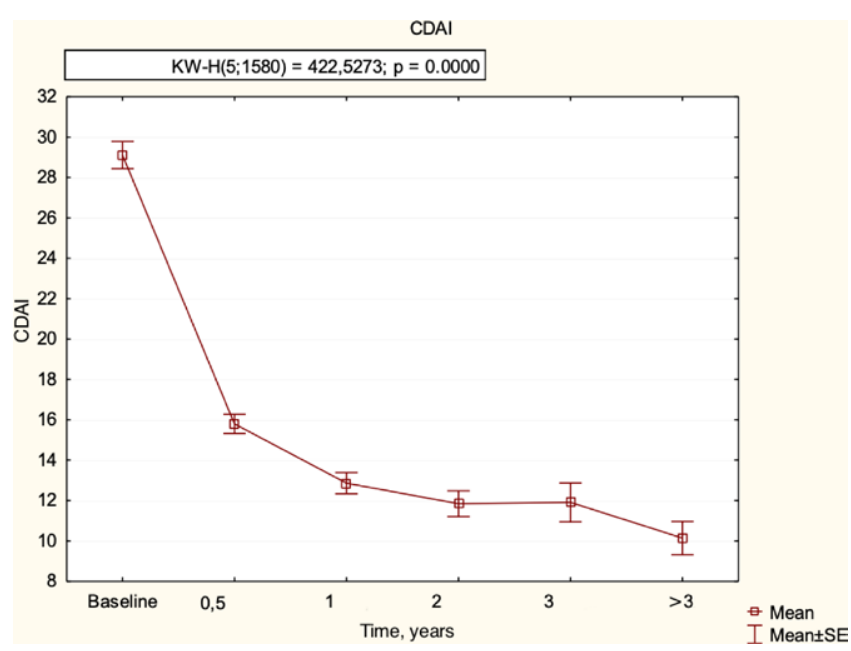

Figure 2. DAS28 of patients with RA, treated with tofacitinib $(n=374)$ - 3-years follow-up (timepoints are presented in years \pm 28 days). 
Table 2. Changes in RA parameters in patients treated with tofacitinib, $\mathrm{n}=374(\mathrm{M} \pm \mathrm{SE})$.

\begin{tabular}{lcccc}
\hline Disease characteristics & Baseline & Year $1^{\#}$ & Year $2^{\#}$ & Year $3^{\#}$ \\
\hline C-RP, $\mathrm{mg} / \mathrm{L}$ & $30.1 \pm 35.0$ & $8.3 \pm 12.8$ & $7.6 \pm 10.7$ & $9.4 \pm 13.5$ \\
ESR, mm/h & $35.2 \pm 21.2$ & $22.7 \pm 17.2$ & $21.9 \pm 17.7$ & $22.3 \pm 17.3$ \\
NTJ from 28 & $11.2 \pm 6.5$ & $4.6 \pm 4.9$ & $4.8 \pm 5.0$ & $3.9 \pm 3.8$ \\
NTJ from 28 & $7.6 \pm 5.1$ & $2.4 \pm 3.2$ & $1.7 \pm 3.1$ & $1.4 \pm 2.8$ \\
\hline
\end{tabular}

*difference with baseline is significant with $p<0.000$. " - \pm 28 days

Conclusion: According to the real world data treatment with tofacitinib may provide good response rates in RA patients, refractory to the previous csDMARDs treatment in long-term perspective.

Acknowledgments : Pfizer

Disclosure of Interests: : Inna Gaydukova Grant/research support from: JSC BIOCAD, Speakers bureau: Pfizer, Novartis, AbbVie, JSC BIOCAD, Celgene, MSD, Sanofi, V Mazurov: None declared, Alexander Lila: None declared, Andrey Baranov Grant/research support from: Bayer, Galina Lukina Speakers bureau: Novartis, Pfizer, UCB, Abbvie, Biocad, MSD, Roche, Evgeniy Zhilyaev Speakers bureau: Novartis, UCB, Pfizer, Biocad, Abbvie, MSD, Roche, Ekaterina Koltsova: None declared, Evgeniya Shmidt Speakers bureau: MSD, Novartis, Pfizer, Oxana Fomina: None declared, Irina Bondareva: None declared, Olga Anoshenkova: None declared, Aleksey Vasilenko: None declared, Elizaveta Vasilenko: None declared, Natalya Yudina: None declared, Larisa Knyazeva: None declared, Vyacheslav Poncratov: None declared, Ekaterina Gaydukova: None declared, Evgeny Nasonov Speakers bureau: Lilly, AbbVie, Pfizer, Biocad, R-Pharm DOI: 10.1136/annrheumdis-2020-eular.4664

\section{SAT0142 MATCHING ADJUSTED INDIRECT COMPARISON OF FILGOTINIB VS. TOFACITINIB IN MODERATE- TO-SEVERE ACTIVE RHEUMATOID ARTHRITIS PATIENTS WITH INADEQUATE RESPONSE TO METHOTREXATE}

M. Gharaibeh ${ }^{1}$, N. Smith ${ }^{2}$, S. Jeyakumar ${ }^{2}$, E. Mark ${ }^{1}$, S. Shreay ${ }^{1} .{ }^{1}$ 1. Gilead Science Inc, Foster City, United States of America; ${ }^{2}$ Maple Health Group, LLC, New York, United States of America

Background: Filgotinib (FILG) is a JAK1 inhibitor that has been investigated in combination with methotrexate (MTX) for the treatment of moderate-to-severe rheumatoid arthritis (RA). To date, no head-to-head trial has compared the efficacy of FILG versus tofacitinib (TOFA).

Objectives: To compare the efficacy of FILG $200 \mathrm{mg}+$ MTX with TOFA $5 \mathrm{mg}$ + MTX using matching adjusted indirect comparison (MAIC).

Methods: MAIC technique uses individual patient data (IPD) from one trial and aggregate data from the other to enable comparison of outcomes after matching on baseline characteristics [1]. An anchored MAIC was conducted using IPD from the FINCH-1 trial of FILG $200 \mathrm{mg}+$ MTX vs adalimumab (ADA) $40 \mathrm{mg}+$ MTX and published data from ORAL STRATEGY [2] trial of TOFA $5 \mathrm{mg}+$ MTX vs ADA $40 \mathrm{mg}+\mathrm{MTX}$. Patients in the FINCH-1 trial were reweighted based on age, sex, race, tender joint count 28 , swollen joint count 28 , C-reactive protein and patient's global assessment to match baseline characteristics of the comparator. After matching, Wald tests were used to test for significant differences in ACR 20/50/70 and clinical remission outcomes (SDAI $\leq 3.3$, CDAI $\leq 2.8$, DAS28(CRP) $<2.6$, Boolean) between FILG + MTX vs TOFA $5 \mathrm{mg}+$ MTX relative to ADA $40 \mathrm{mg}+$ MTX.

Results: After matching, baseline characteristics were balanced across the trial populations [Table 1]. FILG $200 \mathrm{mg}+$ MTX patients experienced significantly greater improvement in 12 week ACR50 and ACR70 outcomes compared to TOFA $5 \mathrm{mg}+$ MTX with a mean difference in difference (DD) of $13.5 \%$ $(p<.05)$ and $8.3 \%(p<.05)$ respectively, as well as numerical improvements on other ACR outcomes at 12, 24 and 52 weeks [Figure 1]. At 24 weeks, FILG $200 \mathrm{mg}+$ MTX patients experienced significantly greater improvement in DAS28(CRP) clinical remission compared to TOFA $5 \mathrm{mg}+$ MTX with DD of $10.1 \%(p<.05)$ [Figure 2] as well as numerical improvements on other efficacy outcomes. At 52 weeks, FILG $200 \mathrm{mg}+$ MTX patients experienced significantly greater improvement in DAS28(CRP) clinical remission compared to TOFA $5 \mathrm{mg}+$ MTX with DD of $13.2 \%(\mathrm{p}<.05)$ [Figure 2] as well as numerical improvements on other efficacy outcomes.
Table 1. Baseline Characteristics of FINCH-1 vs ORAL STRATEGY

\begin{tabular}{|c|c|c|c|c|c|c|}
\hline \multirow[t]{2}{*}{ CHARACTERISTIC } & \multicolumn{4}{|c|}{ BEFORE MATCHING AFTER MATCHING } & \multicolumn{2}{|c|}{ ORAL STRATEGY } \\
\hline & $\begin{array}{c}\text { FILG } 200 \\
+ \text { MTX } \\
(\mathrm{N}=475)\end{array}$ & $\begin{array}{c}\text { ADA } \\
+\mathrm{MTX} \\
(\mathrm{N}=325)\end{array}$ & $\begin{array}{c}\text { FILG } 200 \\
+ \text { MTX } \\
(E S S=340)\end{array}$ & $\begin{array}{c}\text { ADA } \\
+ \text { MTX } \\
(E S S=233)\end{array}$ & $\begin{array}{l}\text { TOFA 5mg } \\
+ \text { MTX BID } \\
(\mathrm{N}=376)\end{array}$ & $\begin{array}{c}\text { ADA + } \\
\text { MTX BID } \\
(\mathrm{N}=386)\end{array}$ \\
\hline Sex - Female, \% & $79.8 \%$ & $81.8 \%$ & $83.0 \%$ & $83.0 \%$ & $83.0 \%$ & $83.0 \%$ \\
\hline Race - White, \% & $65.7 \%$ & $70.5 \%$ & $76.0 \%$ & $76.0 \%$ & $76.0 \%$ & $76.0 \%$ \\
\hline $\begin{array}{l}\text { Tender Joint Count } \\
\text { 28, mean (SD) }\end{array}$ & $15.0(6.4)$ & $14.6(6.3)$ & $15.6(6.5)$ & $15.2(6.7)$ & $15.6(6.5)$ & $15.2(6.7)$ \\
\hline $\begin{array}{l}\text { Swollen Joint Count } \\
28 \text {, mean (SD) }\end{array}$ & $11.2(5.2)$ & $11.2(5.0)$ & $11.8(5.7)$ & $11.0(5.4)$ & $11.8(5.7)$ & $11.0(5.4)$ \\
\hline $\begin{array}{l}\text { C-Reactive Protein } \\
\text { (mg/L), mean (SD) }\end{array}$ & $16.1(21.0)$ & $14.6(18.0)$ & ) $18.7(21.9)$ & 16.7 & $18.7(21.9)$ & ) $16.7(21.3)$ \\
\hline $\begin{array}{l}\text { Patient global assess- } \\
\text { ment baseline, mean } \\
\text { (SD) }\end{array}$ & $-67.1(19.2)$ & $67.0(19.1)$ & $61.7(22.0)$ & $60.2(23.5)$ & 61.7 & $60.2(23.5)$ \\
\hline
\end{tabular}

ESS = effective sample size; $\mathrm{SD}=$ standard deviation

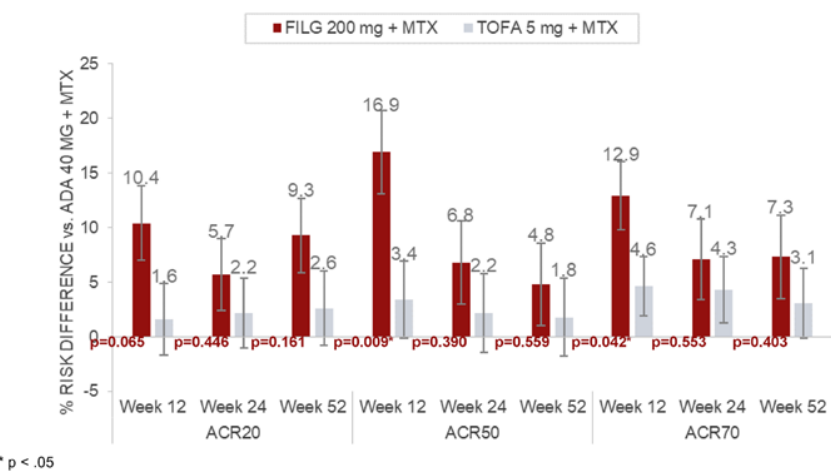

Figure 1. ACR20/50/70 relative to ADA $40 \mathrm{mg}+$ MTX of FILG $200 \mathrm{mg}+$ MTX vs TOFA $5 \mathrm{mg}+$ $\mathrm{MTX}^{*} \mathrm{p}<.05$

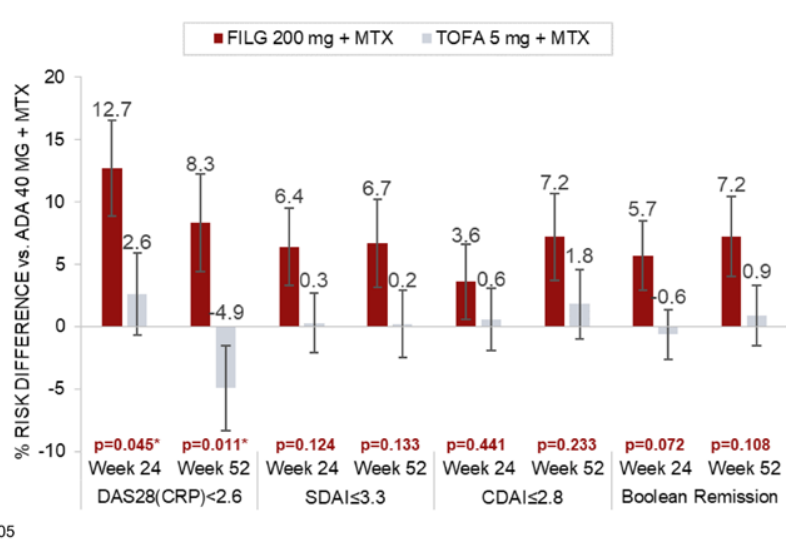

Figure 2. Clinical Remission outcomes relative to ADA $40 \mathrm{mg}+\mathrm{MTX}$ of FILG $200 \mathrm{mg}+$ MTX vs TOFA $5 \mathrm{mg}+$ MTX ${ }^{*} \mathrm{p}<.05$

Conclusion: In this MAIC, compared to TOFA 5mg + MTX, FILG $200 \mathrm{mg}+$ MTX appears to produce improved efficacy outcomes (ACR20/50/70, DAS28(CRP), SDAI, CDAI and Boolean Remission) at weeks 12, 24 and 52.

References:

[1] Signorovitch JE, et al. "Matching-adjusted indirect comparisons: a new tool for timely comparative effectiveness research." Value in Health 15.6 (2012): 940-947

[2] Fleischmann R, et al. "Efficacy and safety of tofacitinib monotherapy, tofacitinib with methotrexate, and adalimumab with methotrexate in patients with rheumatoid arthritis (ORAL Strategy)." The Lancet 390.10093 (2017): 457-468

Acknowledgments: The study was funded by Gilead Sciences Inc 